Kredo 3 (2020)
KREDO: Jurnal Ilmiah Bahasa dan Sastra
Terakreditasi Sinta 4 berdasarkan Keputusan Direktorat
Jenderal Penguatan Riset dan Pengembangan,
Kementerian Riset, Teknologi dan Pendidikan Tinggi
Republik Indonesia
Nomor: 23/E/KPT/2019. 08 Agustus 2019
https://jurnal.umk.ac.id/index.php/kredo/index

\title{
HEGEMONI KEKUASAAN DALAM NOVEL KOPLAK KARYA OKA RUSMINI: KAJIAN SOSIOLOGI SASTRA
}

\author{
Diki Febrianto ${ }^{1}$, Candra Rahma Wijaya Putra ${ }^{2}$ \\ dikifebrianto45@gmail.com ${ }^{1 凶}$, candra_rwp@umm.ac.id ${ }^{2}$
}

Prodi Pendidikan Bahasa Indonesia, Fakultas Keguruan dan Ilmu Pendidikan

Universitas Muhammadiyah Malang

Info Artikel
Sejarah Artikel
Diterima 6 Januari
2020
Disetujui 18 Maret
2020
Dipublikasikan 29
April 2020
Keywords
hegemony,
power, sociology
of literature
Kata Kunci
hegemoni,
kekuasaan,
sosiologi sastra

\begin{abstract}
This study aims to describe the hegemony of power contained in the Oka Rusmini's Koplak novel, which deals with dominating and dominated social groups, supremacy of intellectual and moral leadership, and political groups. This type of research is qualitative research. This research uses descriptive analysis method because it focuses on the situation or process under study or by exploring a phenomenon in a problem. The approach in this research is the approach of literary sociology. The research data source is Koplak's novel by Oka Rusmini. The data in this study are in the form of sentences and paragraphs that have relevance to representations as episodes of time, authorship representations, and representations of history. Data collection techniques used in this study are reading and note taking techniques. The data analysis method used in this study is the Miles and Hubermann model. According to Huberman which consists of four - steps, namely: data collection (data collection), data reduction (data reduction), data display (data presentation), conclusion drawing (withdrawal or verification of conclusions). The results show that people who occupy positions in government, do not always dominate, but can also be dominated. In addition, intellectual leadership and forms through religion and education. Political conflict, shown through the efforts of each candidate for village head candidate.
\end{abstract}

Abstrak
Penelitian ini bertujuan mendeskripsikan hegemoni kekuasaan yang terdapat di dalam
novel Koplak karya Oka Rusmini, yang berkaitan dengan kelompok sosial yang mendominasi dan
didominasi, supremasi kepemimpinan intelektual dan moral, serta kelompok politik. Jenis
penelitian ini yaitu penelitian kualitatif. Penelitian ini menggunakan metode deskriptif analisis
karena melakukan penggambaran yang berfokus kepada situasi atau proses yang diteliti atau dengan
cara mendalami suatu fenomena di dalam suatu masalah. Pendekatan pada penelitian ini adalah pendektan
sosiologi sastra. Sumber data penelitian yaitu novel Koplak karya Oka Rusmini. Data pada penelitian
ini berupa kalimat maupun paragraf yang memiliki relevasi dengan representasi sebagai reflesi
zaman, representasi kepengarangan, dan representasi dari kesejarahan. Teknik pengumpulan data
yang digunakan dalam penelitian ini adalah teknik baca dan catat. Adapun metode analisis data
yang digunakan dalam penelitian ini adalah metode model Miles dan Hubermann. Menurut
Huberman yang terdiri dari empat langkah, yaitu: data collection (pengumpulan data), data
reduction (reduksi data), data display (penyajian data), conclusion drawing (penarikan atau
verifikasi kesimpulan). Hasil penelitian menunjukan, kaum yang menduduki jabatan di
pemerintahan, tidak selalu menjadi yang mendominasi, melainkan juga dapat menjadi yang
didominasi. Selain itu, kepemimpinan intelektual dan moral melalui agama dan pendidikan. Konflik
politik, ditunjukan melalui upaya dari masing-masing kandidat calon kepala desa.




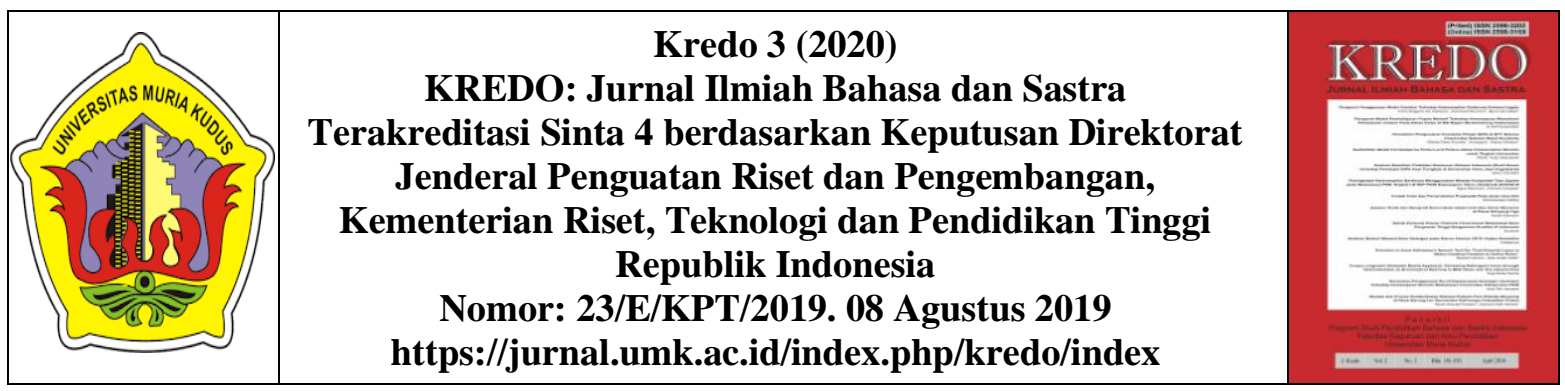

\section{PENDAHULUAN}

Kekuasaan merupakan sebuah konsep yang mendesak kaitanya dengan kajian terhadap peristiwa sosial (Idayatiningsih, 2017:43). Hal ini menjadikan kekuasaan memiliki pengaruh yang besar pada kehidupan manusia di masyarakat. Pewujudan dari adanya suatu kekuasaan disampaikan melalui bahasa, dan dalam pelaksanaanya melalui perantara bahasa. Penggunaan bahasa oleh golongan yang kuatbertujuan untuk mendominasi golongan lemah. Dampak dari adanya kekuasaan akan terlihat dari adanya relasi antara individu dengan individu lainya atau hal ini terjadi pada dua orang maupun lebih. Hadirnya bahasa dapat memberi arti sebagai kaidah sosial yang bersifat memaksa terhadapa seseorang ketika bertutur atau berbicara, dan berpikir. Oleh karena itu, dalam bertutur ataupun berbicara akan menimbulkan pemikiran yang bersifat memaksa juga, atau dalam hal ini bisa dikatakan sebagai pengaruh. Pengaruh melalui bahasa tersebut merupakan salah satu upaya untuk meciptakan kekuasaan.

Kekuasaan sangat erat kaitanya dengan politik yang berkuasa pada suatu periode. Kekuasaan dipandang hanya terkait politik, tanpa kita sadari, individu yang dapat mempengaruhi individu lain, denga tujuan meyakinkan terkait pembahasaanya, adalah salah satu bentuk kekuasaan atau hegemoni. Permasalahan terkait kekuasaan menarik untuk dibahas, khususnya di dalam novel dengan judul Koplak oleh Oka Rusmini. Hal ini sebagai pengungkapan terhadap kekuasaan di suatu periode yang memiliki tujuan dan kepentingan tertentu. Dalam hal ini, sebuah kelompok sosial dapat dapat dan harus melaksanakan suatu kepemimpinan sebelum dinyatakan atau mendapat sebuah kekuasaan. Jika sebuah kekuasaan didapat dan menjalankan sebuah kepemimpinan, maka ia bisa dikatakan sebagai dominan. Hal ini sesuai dengan pernyataan Gramsci tentang studi yang didasarkan kepada asumsi, jika supremasi kelompok sosial dalam menyatakan dirinya. Selain itu, juga terdapat istilah kepemimpinan moral dan intelektual, yang berkaitan langsung pada kondisi mental dan kecerdasan seseorang. Oleh karena itu, dalam menciptakan sebuah karya sastra, akan mengandung cerita yang menarik jika memiliki relasi terhadap kekuasaan pada suatu periode.

Oka Rusmini seorang penulis novel, puisi, dan cerpen. Salah satu karyanya dengan judul Saibah pernah meraih penghargaan Kusalah Sastra Khatulistiwa kategori puisi. Karyanya yang fenomenal dan mengunadang kontroversial karena beberapa karyanya mengangkat persoalan adat istiadat dan tradisi yang berada di Bali, membuat ia beberapa kali diundang dalam acara kesusastraan nasional maupun internasional. Salah satu novelnya yang memiliki latar tempat di Bali dengan judul Koplak. Novel dengan judul yang unik, berisi tentang kisah seorang I Putu Koplak, seorang lelaki Koplak yang melihat fenomena kehidupan dengan cara karikatural. Koplak menjabat sebagai kepala desa di Bali, Desa Sawut. Berlatar belakang seorang petani, ia hidup dengan mengandalkan hasil pertanian. Seorang Koplak bukanlah penguasa yang angkuh ataupun 


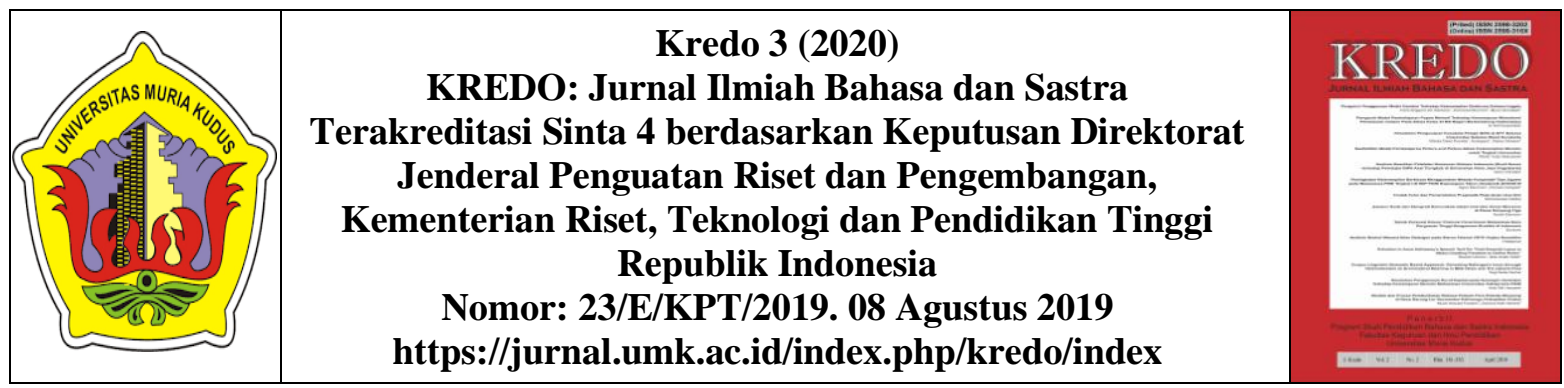

memanfaatkan kekuasaanya menyelesaikan untuk menyelesaikan persoalan hidupnya. Oleh karena itu, fenomena yang tercermin dalam novel dengan judul Koplak.

Novel adalah salah satu jenis karya sastra yang diciptakan pengarang yang memiliki kaitanya dengan masyarakat (Setiawan, 2018:106). Novel sebagai wujud karya sastra tercipta dari kisah nyata dan sebagai bentuk imajinasi pengarang terkait suatu kenyataan. Karya sastra dipandang sebagai refleksi dari kehidupan di masyarakat yang mengandung berbagai fenomena masalah (Rahmat, 2019: 83). Selain itu, karya sastra dari sudut pandang Saussure menempatkan bahasa sebagai fenomena sosial, kiranya hal ini dipengaruhi oleh ilmuwan sosiologi yaitu Durkheim yang membahas tentang fakta sosial (Widada, 2009: 14). Interaksi dalam anggota masyarakat, akan muncul berbagai gejala atau fenomena misalnya sistem kekerabatan, tradisi, adat-istiadat, dan semua terkait perilaku secara keseluruhan, merupakan perwujudan tersendiri.

Karya sastra memiliki pengertian mengenai sesuatu hal yang disepakati dan pasti secara bersama, jika karya sastra merupakan sebuah perihal yang berkaitan dengan kebahasaan. Sastra hadir dengan membentuk serangkaian bunyi dengan pola yang memiliki aturan tertentu atau dapat diartikan sebagai keadaan dari adanya permasalahan kebahasaan, sehingga pada pemerolehan intelektual melalui sastra dapat diperoleh melalui pengetahuan tentang bahasa (Widada, 2009:09).

Fenomena seperti inilah yang dimaknai sebagai fakta sosial. Tetapi fakta sosial bukan gejala psikologi, karena fakta sosial berada pada luar kemampuan atau kekuasaan sadar seorang individu. Bahasa adalah sarana paling sesuai atau efektif dalam menuangkan ide maupun mengungkapkan perasaan yang dituangkan dalam bentuk karya sastra (Nakrowi, 2019). Karya sastra hadir oleh kreativitas pengarang terhadap ide yang dimilikinya. Salah satu sumber ide yaitu kehidupan manusia sebagai sumber inspirasi pengarang. Meskipun karya sastra meruapakan hasil imajinasi, banyak pelajaran hidup yang didapat dari karya sastra, misalnya cerita di dalam sebuah novel.

Novel Koplak menceritakan kisah seorang bernama I Putu Koplak. Tokoh Koplak melihat segala permasalahan hidup dengan caranya sendiri. Semua kejadian di dalam hidup, dilihat dari sudut pandang Koplak adalah sebuah lelucon. Sebagai karya sastra, di dalam novel Koplak menyimpan sebuah kenyataan sosial yang terdapat di dalamnya. Untuk mengungkap hal itu, dapat melalui pendekatan sosiologi sastra. Sosiologi sastra relevan sekali dengan adanya fenomena terkait manusia. Sosiologi secara universal dapat diartikan sebagai kajian, yang memiliki objek manusia dan masyarakat, di dalamnya terjadi proses sosial (Wahyudi, 2013: 55). Bahan kajian sosialogi sastra berfokus kepada gejala sosial yang harus dipaparkan secara ilmiah. Kaitanya dengan karya sastra, sosiologi sastra digunakan sebagai pengkonstruksi relasi antara manusia, masyarakat, keluarga, politik, agama, dan aspek sosial lainnya. Beberapa jenis sastra, salah satunya novel, mengandung 


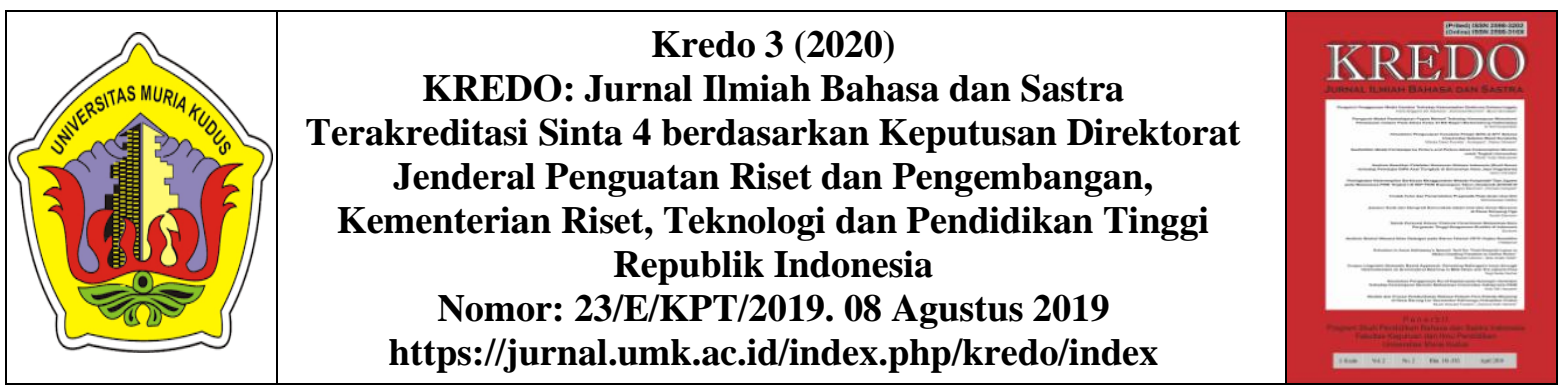

segala persoalan yang berkaitan dengan kajian sosiologi sastra. Damono, (1979:68) menyatakan bahwa, novel sebagai karya sastra mengangkat persoalan yang dibahas oleh sosiologi, yaitu masyarakat dan segala kegiatan di dalamnya.

Penelitian yang relevan dengan kajian ini sebagai upaya untuk membantu pengembangan tulisan ini yaitu, pertama, oleh Falah, (2018) dengan judul "Hegemoni Ideologi dalam Novel Ketika Cinta Bertasbih Karya Habiburrahman el Shirazy (Kajian Hegemoni Gramsci)" dengan tujuan mengungkap bentuk hegemoni ideologi, yang menunjukan Khairul Azzam dan Anna Althafunnisia yang mampu menjalani hidupnya dengan adanya persoalan pendidikan, percintaan, dan pernikahan. Relevansinya terhadap penelitian ini yaitu terletak pada pendekatan yang digunakan yaitu sosiologi sastra Gramsci. Kedua, dengan judul Cerminan Zaman dalam Puisi (Tanpa Judul) Karya Wiji Thukul: Kajian Sosiologi Sastra oleh Putra, (2018). Hasil penelitian ini mengungkap bahwa puisi ciptaan Wiji Thukul adalah cerminan pada masa Orde Baru.

Puisi Wiji Thukul dengan judul (Tanpa Judul), menggambarkan adanya tekanan yang dialami pengarang dan masyarakat pada era Orde Baru. Ketiga, dengan judul Kajian Sosiologi Sastra dan Nilai Pendidikan dalam Novel "Tuan Guru" Karya Salman Faris oleh Akbar, (2012). Hasil adanya kajian ini berfokus kepada kepengarangan dari novel Tuan Guru karya Salman Faris. Penelitianya mengungkap bahwa sebagian besar masyarakat Lombok Timur berdasarkan sudut pandang pengarang yang menangkap bahwa tuan guru adalah sosok yang dapat menjamin masuk surge, doanya lebih cepat dikabulkan Allah dibandingkan dengan yang lain, hal ini merupkan bentuk sosiobudaya masyarakat.

"it is the task of sociologist of literature to relate the experience of the writer's imaginary characters and situations to the historical climate from which they derive. He has to transform the private equation of theme and stylistic means into social equations" (Swingewood, 1992:14).

Alan menjelaskan jika, sosiologi sastra digunakan untuk menelisik karya sastra yang di dalamnya memiliki relasi antara pengalaman dan kejadian imajiner pengarang dengan cerita sejarah atau historis. Dalam hal ini, karya sastra merupakan transformasi terhadap pengalaman pribadi pengaran terhadap tema dan gaya dalam karya sastra menjadi persamaan sosial. Oleh karena itu, sosiologi sastra Alan Swingewood lebih tepat jika digunakan dalam mengungkap karya sastra yang di dalamnya memiliki cerita historis.

Sebuah teori sebelum adanya Alan Swingewood, muncul teori hegemoni, yang lahir dari pemikiran Marxisme. Teori hegemoni lahir dari adanya pemikiran kaum Marxist yang pada saat itu terjadi kekuasaan yang monarki di Rusia. Oleh karena itu, seluruh pembahasan terkait hegemoni mengalir dalam pemikiran Marxisme. Tetapi, saat ini konsep hegemoni dipandang sebagai suatu kenetralan dalam memandang berbagai bentuk hubungan kekuasaan di dunia politik, ekonomi, sastra, sosial, dan budaya. Hegemoni berkaitan erat dengan kekuasaan dan sebuah ideologi. 

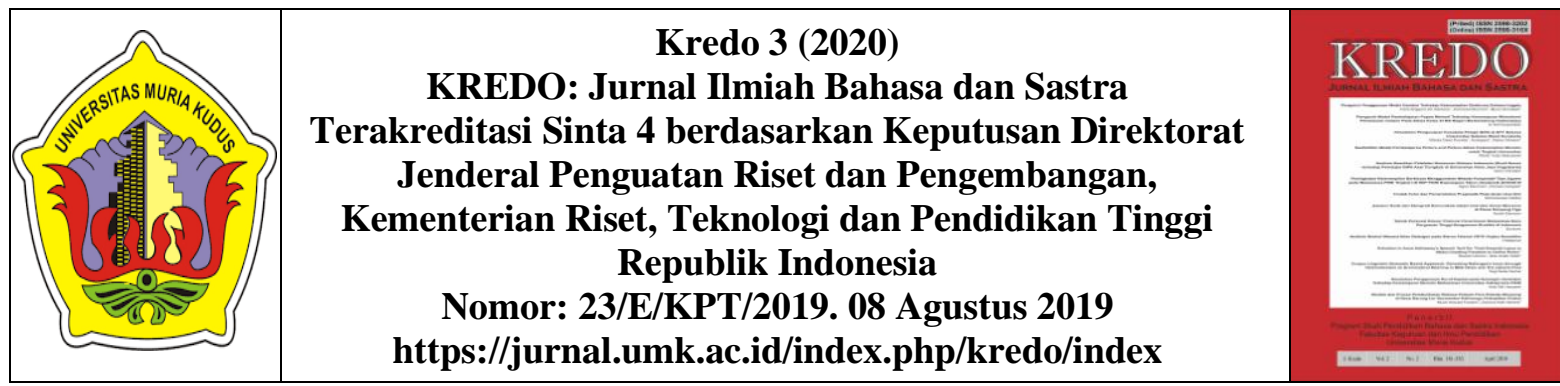

Sudut pandang Gramsci terkait hegemoni merupakan praktik yang memiliki dua arah yang bersifat subordinasi, yaitu kekuasaan negara borjuis atau kelas masyarakat dari kalangan menengah ke atas, dan kelas buruh ataukalangan bawah (Hutagalung, 2004:1).

Hegemoni adalah salah satu bentuk kekuasaan dan kepemimpinan yang didapat melalui consensus maupun persetujuan, (Falah, 2018:536). Oleh karena itu, sebuah kekuasaan dan kepemimpinan yang didapat bukan karena keterpaksaan, melainkan didapat dengan cara kedamaian. Mekanisme kepemimpinan didapatkan melalui cara politis dan ideologi Gramsci, (1971:57). Dalam konsepnya, hegemoni tidak hanya dilihat dari skala besar antar negara, melainkan juga dalam skala keci antara individu maupun personal. Individu maupun kelas sosial tertentu berkuasa terhadap individua tau kelompok tertentu melalui persetujuan dan ideologi. Ideologi dalam perspektif karya sastra dipandang sebagai gagasan, kesadaran, dan sebuah keyakinan yang dipercayai masyarakat di dalam kehidupan (Falah, 2018:102).

Penelitian ini memfokuskan pada pendekatan sosiologi sastra menggunakan teori hegemoni Gramsci. Teori ini merupakan hasil dari pemikiran Gramsci terhadap hegemoni yang dibangun atas kepentingan suatu ide dan tidak dapat mencangkup terhadap fisik dalam kontrol sosial dan politik. Agar penguasa dapat menguasai yang dikuasai, dan yang dikuasai tidak hanya harus merasa memiliki dan menghayati nilai dan moral dari penguasa, dan lebih dari itu keduanya harus mengadakan persetujuan atas kedudukan dari keduanya. Hal ini yang disebut dengan

208 | Jurnal Kredo

Vol. 3 No. 2 April 2020 "hegemoni" atau penguasaan kepemimpinan intelektual dan moral secara konsensus. Konsep hegemoni menurut Gramsci agar dapat memiliki masa waktu yang lama, paling tidak membutuhkan perangkat kerja yaitu, pertama, perangkat kerja melalui tindakan kekerasan, hal ini bersifat terikat dan memaksa atau kekuasaan bernuansa law enforcement. Kedua, perangkat kerja yang merayu atau membujuk masyarakat untuk tunduk dan taat terhadap mereka yang berkuasa melalui berbagai bidang kehidupan yaitu, pendidikan, agama, kesenian, dan keluarga.

Penelitian ini akan mengungkap kekuasaan yang terdapat di dalam novel Koplak karya Oka Rusmini melalui pendekatan sosiologi sastra. Jawaban dari rumusan masalah nantinya akan memaparkan yaitu, pertama, kelompok sosial yang mendominasi pada novel Koplak. Kedua, supremasi kepemimpinan intelektual dan moral pada novel Koplak.

\section{KAJIAN TEORI}

Menurut Gramsci, menyatakan bahwa, kriteria dalam metodologis sebagai dasar sebuah studi, didasarkan asumsi bahwa supremasi golongan kelompok sosial menyatakan melalui du acara, yaitu dominasi dan kepemimpinan moral. Kelompok sosial yang mendominasi golongan antagonistik yang memiliki kecenderungan untuk menghancurkan atau bahkan dilakukannya pembinasaan dengan menggunakan tantara. Kelompok 


Kredo 3 (2020)
KREDO: Jurnal Ilmiah Bahasa dan Sastra
Terakreditasi Sinta 4 berdasarkan Keputusan Direktorat
Jenderal Penguatan Riset dan Pengembangan,
Kementerian Riset, Teknologi dan Pendidikan Tinggi
Republik Indonesia
Nomor: 23/E/KPT/2019. 08 Agustus 2019
https://jurnal.umk.ac.id/index.php/kredo/index

tersebut dalam kepemimpinannya juga memimpin golongan yang sama yang memiliki aliansi bersamanya.

Wellek dan Weren menjelaskan jika sosiologi memiliki tiga klasifikasi, yang akan disebutkan sebagai berikut. Pertama, sosiologi dari sudut pandang kepengarangan, fenomena yang dapat dipermasalahkan terhadap ideologi politik, status sosial, dan lain-lain, yang menyangkut pengarang. Kedua, sosiologo terkait karya sastra, didasarkan terhadap karya sastra yang menjadi objek kajian terkait tujuan dan amanat yang terkandung di dalamnya. Ketiga, sosiologi yang berfokus kepada masalah tentang pengaruh sosial dan pembaca terhadap masyarakat (Semi, 1993: 53).

Damono, (1984) menjelaskan tentang relasi timbal-balik terkait pencipta (sastrawan), sastra, dan masyarakat. Ketiga aspek tersebut saling berkaitan dari konteks sosial pengarang, yang dapat mengungkap posisi sosial sastrawan di dalam masyarakat dan relasinya terhadap pembaca. Selain itu, telah dijelaskan bahwa sastra sebagai cerminan zaman atau masyarakat, yang selanjutnya menekankan kepada fungsi sosial sastra yang memiliki pengaruh terhadap sudut pandang sosial. Penilaian terhadap sosial masyarakat, akan terwujud baik buruknya keadaan sosial di suatu masa yang tersirat di dalam karya sastra (Wijakangka, 2008:189).

Terkait penelitian ini, akan mengungkap keadaan sosial yang menyangkut hegemoni dan kekuasaan di dalam novel Koplak karya Oka Rusmini. Hegemoni merupakan pemimpinan dan kekuasaan yang dapat diperoleh dengan cara persetujuan atau konsensus dan bukan dengan cara keterpaksaan (Falah, 2018: 536). Pernyataan tersebut tidak lepas, kaitanya dengan pernyataan
Gramsci sebagai pencetus teori hegemoni. Konsep hegemoni yang dikemukakan Gramsci, memiliki relasi dan mengacu kepada civil society dan state atau negara. Keduanya tercipta atas struktur yang dibangun atas struktur lain, bahwa Gramsci berpatokan kepada pemikiran Marx.

What we can do, for the moment, is to fix two major superstructural 'levels': the one that can be called 'civil society', that is the ensemble of organisms commonly called 'private', and that of 'political society' or 'the State'. These two levels correspond on the one hand to the function of 'hegemony' which the dominant group exercises throughout society and on the other hand to that of 'direct domination' or command exercised through the State and 'judicial' government. (Gramsci, 1971).

Gramsci menjelaskan faktor penting terkait intelektual di dalam pemikiran tentang hegemoni. Relasi terkait intelektual dan wilayah produksi bersifat tidak langsung, tidak seperti kelompok sosial secara mendasar yang masuk kedalam suatu hubungan misalnya buruh dan pemilik modal, tapi dalam tingkatan yang bertolak belakang "dimediasi" oleh produksi yang tercipta oleh masyarakat dan kerumitan yang terjadi di wilayah superstruktur. Hal ini, kaum intelektual akan menjadi sebagai fungsionarisnya (Hutagalung, 2004: 9-10). 


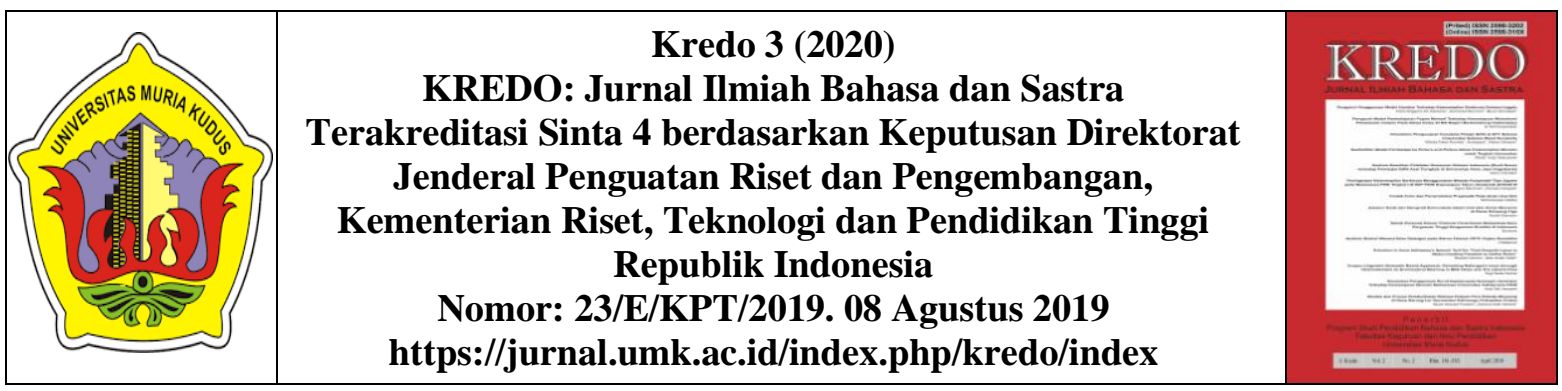

\section{METODE PENELITIAN}

Jenis penelitian ini yaitu penelitian kualitatif. Penelitian ini menggunakan metode deskriptif analisis karena melakukan penggambaran yang berfokus kepada situasi atau proses yang diteliti atau dengan cara mendalami suatu fenomena di dalam suatu masalah. Pendekatan pada penelitian ini adalah pendektan sosiologi sastra. Sumber data penelitian yaitu novel Koplak karya Oki Rusmini. Data pada penelitian ini berupa kalimat maupun paragraf yang memiliki relevasi dengan representasi sebagai reflesi zaman, representasi kepengarangan, dan representasi dari kesejarahan. Teknik pengumpulan data yang digunakan dalam penelitian ini adalah teknik baca dan catat. Adapun metode analisis data yang digunakan dalam penelitian ini adalah metode model Miles dan Hubermann. Menurut Huberman yang terdiri dari empat langkah, yaitu: data collection (pengumpulan data), data reduction (reduksi data), data display (penyajian data), conclusion drawing (penarikan atau verifikasi kesimpulan) (Miles \& Huberman, 2009: 30).

\section{HASIL DAN PEMBAHASAN}

\subsection{Supremasi Kepemimpinan \\ Intelektual dan Moral}

Sudut pandang Gramsci terkait hegemoni merupakan praktik yang memiliki dua arah yang bersifat subordinasi, yaitu kekuasaan negara borjuis atau kelas masyarakat dari kalangan menengah ke atas, dan kelas buruh ataukalangan bawah (Hutagalung, 2004: 1). Gramsci berpendapat jika kekuasaan agara dapat dipertahankan melalui salah satunya dengan kekuasaan yang mendominasi. Dominasi disini yaitu lebih kearah tindakan kekerasan dan bersifat memaksa atau dengan kata lain law enforcement. Tindakan tersebut dapat diwujudkan melalui lembagalembaga seperti militer, polisi, hukum, dan penjara. Kekuasaan dalam teori Gramsci dapat dicapai dengan mengandalkan kekuasaan yang terikat atau memaksa. Hasil dari capaian yang terwujud diberi istilah "dominasi". Tujuan dari tercapainya stabilitas dan keamanan di wujudkan, tetapi sebuah gejolak pertentangan tidak nampak terlihat karena ketidak berdayanya rakyat.

Kaitanya dengan novel Koplak karya Oka Rusmini didominasi oleh lingkungan yang borjuis atau kalangan menegah atas. Lingkungan yang didominasi oleh sebuah pengetahuan yang berkembang. Hal ini ditunjukan melalui data sebagai berikut.

"Bape jangan kampungan, dong. Sebagai apparat, Bape harus mengikuti tata krama dan tata bahasa yang baik. Tata laku yang perlu dirubah. Bape harus mulai belajar table manner!" (Rusmini, 2019:14).

Begitulah perkataan yang dilontarkan oleh putri semata wayang Koplak. Ia menjelaskan kepada Bapenya terkait tata krama yang harus dilakukan seorang aparat. Seorang aparat harus bertingkah baik dan memiliki etika dalam memakan maupun minum. Di era yang modern saat ini, semua memiliki aturan. Tetapi berbeda dengan Koplak yang menganggap semua itu sebagai sesuatu masa buduh. 


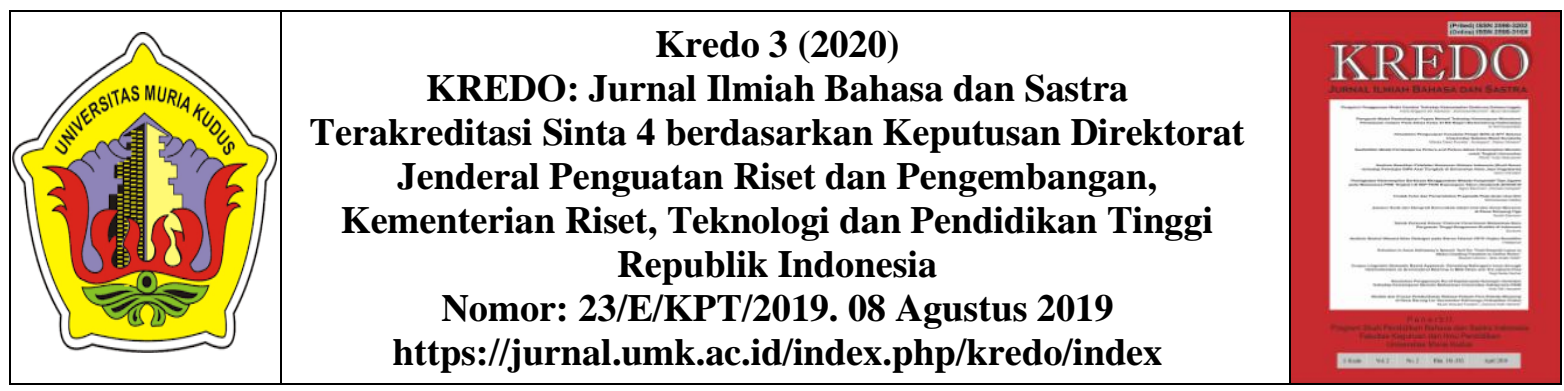

"Memang saat ini adalah zaman buduh. Zaman "gila". Semua hal ada aturannya. Aturan-aturan yang membuat orang tidak nyaman. Tidak juga menetramkan, apalagi memberi pencerahan.

Aturan-aturan masyarakat modern itu begitu banyak. Seolah seluruh hal bisa dibuatkan bhisama." (Rusmini, 2019:14).

Soerang Koplak yang memiliki pemikiran seperti orang menegah kebawa, menjadikan dirinya tetap menjabat sebagai kepala desa. Karena semua permasalah tidak perlu diselesaikan dengan suatu kemodernan. Koplak memiliki cara tersendiri memandang sebuah kemajuan, dalam perspektif ini, Koplak memiliki pandangan yang bertolak belakang terhadap kemajuan sebuah zaman. Oleh karena itu, Koplak meskipun memiliki kekuasaan, dalam hal ini kekuasaan yang dimiliki Koplak tidak dapat mendominasi melainkan didominasi, dan sebagai yang mendominasi adalah lingkungan Koplak yang modern, melalu pernyataan anaknya.

"Kata-kata Pan Jacob terngiangngiang di mata, juga terdengar di telinganya. Orang gila, laki-laki maupun perempuan, sering kali kita jumpai telanjang bulat di tengah jalan ramai.” (Rusmini, 2019:48)

Data di atas menunjukan jika Koplak telah mendapatkan hegemoni oleh penyataan Pan Jacob melalui opini. Dalam hal ini, Koplak telah mendapat hegemoni yang menjadikannya teringatingat tentang pernyataan Pan Jacob, sehingga yang mulanya Koplak memiliki watak keras, tegas, galak, dan beruntal. Sehingga tidak ada keputusan yang membuat jantung, hati, aliran darahnya bisa terhenti.
Strategi perangkat kerja dalam kepemimpinan intelektual dan moral ditujukan untuk membujuk masyarakat agar taat kepada penguasa melalui pendidikan, agama, seni, dan kekeluargaan (Heryanto, 1997). Perangkat kerja dalam hal ini dilakukan oleh masyarakat sipil atau civil society.

"Sekarang ini zaman serba cepat Bape. Terus Bape harus bagaimana?. Bape harus mempersiapkan timses. Apa itu?. Tim sukses untuk mendukung Bape jadi pemenang di pemilihan kades. Kalua mau menang, Bape harus punya timses. Gawat sekali. Bape, Bape, makanya kalua baca koran dan nonton TV itu didengar baik-baik informasinya. Bape lihat, kan, pesaing untuk meraih kursi gubernur di kota?. Waduh, itu rumit dan menakutkan. Bape, kan, Cuma mau ikut pemilihan kades, bukan gubernur. Iya, ngerti. Tetapi, yang harus ditiru itu sistemnya.

Strategi yang dimiliki anak Koplak, melalui pengetahuan atau intelektualnya terkait upaya yang harus dilakukan Koplak dalam merebutkan kursi sebagai Kepala Desa. Melalui pendidikan yang, menjadikan mora dari putri Koplak yang mendorong Koplak untuk membentuk tim sukses. Hal ini tidak luput dari adanya perkembangan zaman, khususnya di dalam bidang politik.

"Koplak menarik napas panjang. Saat ini, kata (agama) menjadi begitu berkuasa dan sangat menakutkan. "Jangan coba-coba menghina orang. Bisa jadi kamu akan di-bully seumur hidup," kata seorang teman 


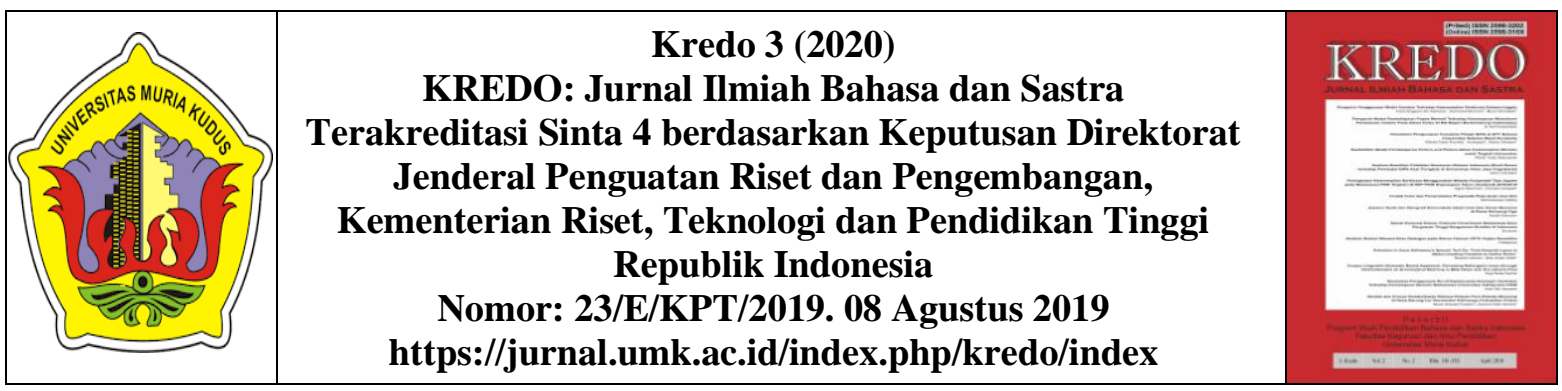

mengingatkan Koplak." Menjadi pemimpin saat ini harus selalu waspada. Sekali salah langkah, kau akan masuk lubang neraka!" (Rusmini, 2019:57).

Pengetahuan sorang teman, yang memberi nasihat kepada koplak. Hal ini merupakan bentuk intelektuan dalam bidang agama, yang mengingatkan kepada Koplak, agar tidak selalu menjadi orang yang menghina orang lain dan mem-bully. Hal itu, akan berakibat kepada dosa yang akan dibuat, sehingga nantinya akan masuk neraka sebagai konsekuensinya. Di dalam agama, sesuatu yang dianggap buruk, akan mendapat konsekuensi yang berupa neraka. Begitu dengan sebaliknya, jika perbuatannya selama di dunia baik, makan akan mendapat konsekuen yaitu berupa surga.

Namun, pagi ini terasa berbeda. Langit-langit kamarnya terasa kusam, buram, dan muram. Koplak berdialog dengan dirinya. Apakah kemenangannya sebagai Kades putaran kedua kali ini adalah hal tulus yang dilakukannya? Sesungguhnya dia mencintai "rakyat" pemilihan di desanya dengan sepenuh hati. Tanpa keinginan untuk menjadi populis, atau ingin dihormati, atau lapar kekuasaan seperti orang-orang di kota yang kelihatan sekali ingin dilirik Presiden Jokowi jadi wapres. (Rusmini, 2019:134).

Moral sebagai pemimpin yang dipikirkan Koplak adalah bentuk evaluasi terhadap dirinya sendiri. Dalam ia berpikir seperti kutipan di atas, membuktikan bahwa moral dan intelektual seseorang harus seperti Koplak. Berpikir tidak cukup satu kali, melainkan harus berpikir ulang sebelum melangkah. Pemikiran Koplak dalam merenung dan berbicara sendiri adalah cara sebuah kepemimpinan yang akan melakukan sebuah tindakan melalui pemikiran atau intelektual yang dimiliki.

"Aku sudah 5 tahun lebih jadi Kades. Kemitir juga tidak menyulitkanku, walau dia anak semata wayang. Koplak menatap Balang. Balang terdiam. Aku merasa dirimu itu tidak mengurus diri. Maksudmu? tanya Koplak sedikit mengernyitkan dahinya. Lihat rumahmu. Tidak terurus. Mendengar jawaban Balang, Koplak tertawa keras. Kali ini Balang yang mengernyitkan dahinya. Kemudia, melanjutkan perkataan pelan kepada koplak. Rumah itu cermin dari penghuninya. Rumahmu kusam. Muram! Kata-kata itulah yang terus terngiang-ngiang seperti keropeng yang menghiasi kulitnya. Seтua dinding rumah memang tidak terlihat bersih, tetapi tidak juga kotor-kotor amat. Ya, Koplak setuju dengan katakata Balang. Kondisi rumah mencerminkan karakter penghuninya. Kalau rumah berantakan, seperti itu juga gambaran jiwa penghuninya. (Rusmini, 2019:131-132).

Pembahasan antara Koplak dan sebagai Kades dan Balang. Pengetahuan tentang kebersihan Balang dapat menghegemoni Koplak. Hal ini dibuktukan dengan cara Koplak menaggapi Balang. Koplak sadar bahwa kebersihan rumahnya adalah sebagai cermin dari penghuni atau pemiliknya.

Ah, keropeng itu tumbuh di pikirannya. Membuat Koplak tidak nyaman minum kopi pagi ini. Masa 


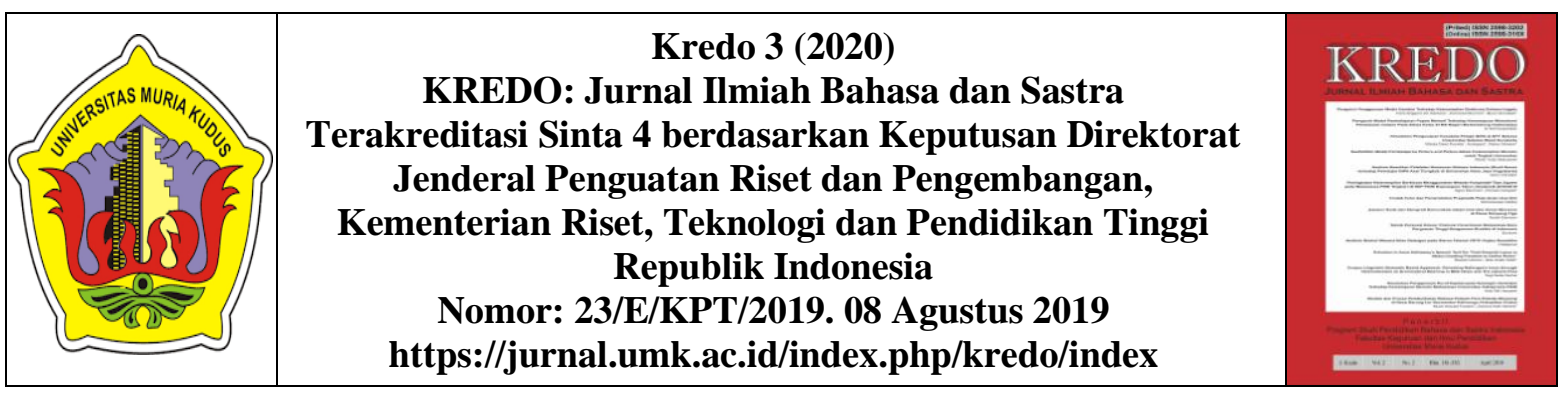

depan apa yang harus aku siapkan untuk diriku sendiri? Koplak terdiam, berusaha menilai diri sendiri, sebelum menilai orang lain lebih buruk atau lebih baik. (Rusmini, 2019:134).

Upaya yang dilakukan tokoh Kopra adalah berpiki melalui intelektual nya terhadap keadaannya. Oleh karenanya, tokoh koplak berpikir terhadap dirinya sendiri untuk di masa yang akan datang. Hal ini karena tokoh koplak mendapatkan hegemoni dari lawan bicaranya sebagai salah satu hegemoni melalui bahasa. Sebagai pemimpin dalam hal ini Koplak selain memikirkan orang lain yang tak lain warganya, dia juga berpikir terhadap dirinya.

Koplak terdiam. Pikirannya buntu. Apakah dia akan dihukum jika memperkerjakan Lindung di kantornya? Apakah orang-orang yang membuat Undang-Undang itu sadar bahwa bukan maksud Koplak "mengeksploitasi" anak-anak seperti Lindung. Anak-anak yang di dalam hidupnya tidak bisa "memilih" orang tua, tidak juga bisa "menentukan" lahir di dalam keluarga seperti apa. (Rusmini, 2019:126-127).

Pengetahuan akan seorang pemimpin yang melihat rakyatnya memiliki keterbatasan, menggerakkan tokoh Koplak untuk mempekerjakan seorang anak bernama Lindung. Hal ini bukan semata-mata Koplak untuk mengeksploitasi anak dibawah umur untuk bekerja, melainkan ini adalah bentuk rasa kasihan seorang pemimpin terhadap rakyatnya yang tidak memiliki keluarga yang jelas di dalam kehidupannya. Dalam hal ini ini pemikiran seorang Koplak terhadap UU perlindungan anak ditentang oleh-nya. oleh karenanya, ini bukan karena paksaan melainkan adalah sebuah bentuk penanggulangan terhadap suatu kondisi. Pada sudut pandang anak, tidak merasakan paksaan. Tindakan yang dilakukan Koplak adalah upaya dalam mensejahterakan rakyatny.

"Sejak kecil Koplak telah diajari cara mengenal-Nya dengan caracara sederhana. Saiban setiap hari itu bukan berarti kamu menyogok Ide Bhatara untuk memenuhi segala keinginanmu, Koplak. Saiban yang kau siapkan itu tanda syukur kita bisa makan hari ini. Itu kata-kata yang diingat Koplak dari Dadong neneknya. Terus kalau berdoa saja harus melalui rapalan mantra-mantra orang seperti Jagra, bagaimana tanda-tandanya doa kita diterima? Sejak kapan Tuhan merasa lelah dan perlu asisten?" (Rusmini, 2019: 139).

Data di atas menunjukkan pendidikan moral dan pengetahuan sebagai intelektual beragama tokoh Koplak. Sebagai pemilik kekuasaan di desanya, sejak kecil ia telah diajarkan mengenal sang pencipta dengan caracara sederhananya. Setiap hari saiban yang disiapkan sehari-hari itu adalah wujud rasa syukur atas apa yang kita terima ketika itu semasa hidup. Hal itu diperoleh Koplak melalui neneknya. Pertanyaan tentang diterimanya sebuah doa dan rasa lelah Tuhan adalah salah satu bentuk bahwa kita tidak akan mengetahui itu karena hal-hal semacam itu adalah urusan Tuhan.

"Buddha Gautama memberikan nasehat perihal kerukunan hidup. Bagaimana agar saling dikenang, saling mencintai saling menghormati, 


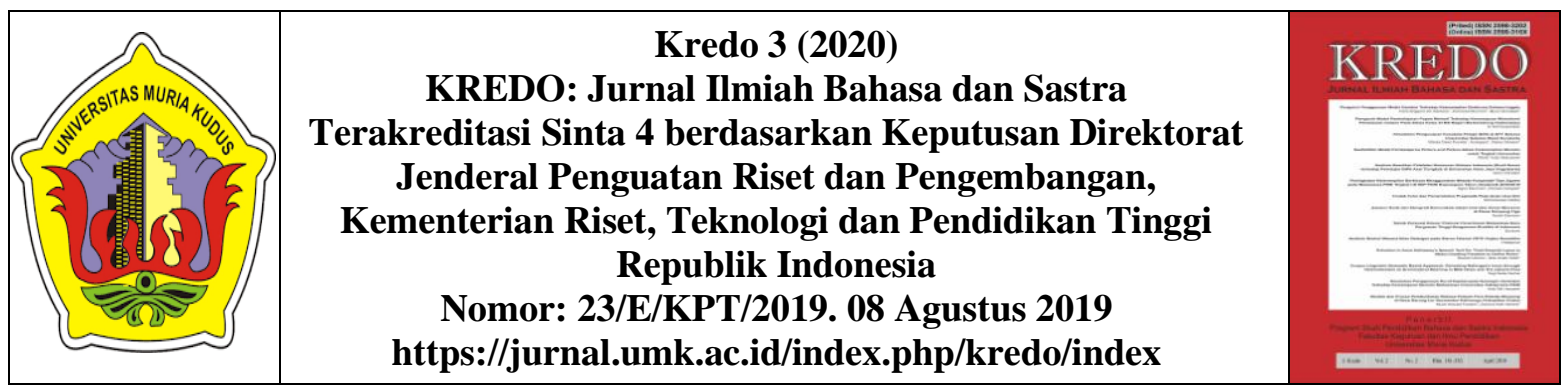

saling menolong memiliki kepedulian, menjaga keutuhan persatuan dengan cara bertindak, berucap, dan berpikiran disertai cinta kasih terhadap sesamanya. Jika membantu orang lain disertai pikiran cinta kasih, begitu pula berbicara disertai pikiran cinta kasih, dan sekalipun berpikir, maka pikirannya diliputi cinta kasih, bebas dari membenci. Di samping itu ia senang berbagi, menolong sesama. Ia juga memiliki kesepahaman dalam hal moral kebaikan dan pandangan benar terhadap kehidupan ini." (Rusmini, 2019:176).

Agama adalah salah satu aspek yang berpengaruh di dalam kehidupan Koplak terhadap moral dan intelektualnya. Ia selalu belajar dari Buddha Gautama ketika melakukan segala sesuatu di kehidupan ini kita harus melakukannya dengan cinta kasih. Cinta kasih ke sesama orang yang berada di lingkungan kita. Begitu pula yang dilakukan Koplak terhadap lingkungannya, mengingat ia merupakan pemimpin yang harus bersikap adil.

\subsection{Konflik Politik dalam Novel Koplak}

Konflik politik merupakan permasalahan yang terjadi adanya pihak yang terkait dalam konflik dengan upaya memperoleh kekuasaan dengan jumlah yang terbatas dan menggunakan kekuasaan atau kelebihan dalam memperolehnya. Hal ini, seseorang akan mendapatkan sebuah kekuasaan dengan cara menggunakan sesuatu kelebihan yang dimilikinya. Dalam penelitian ini, bentuk dari konflik politik dalam memanfaatkan sebuah kedudukan dan jabatan yang dimiliki.

"Calon pertama adalah seorang anak muda, ganteng. Senyumnya mampu mematahkan seluruh kuncup bunga yang ada di desa. Ketika berjalan, dadanya selalu dibusungkan. Kepalanya terangkat dengan senyum yang selalu tersungging di bibirnya yang kelihatan sangat hitam karena kebanyakan merokok. Anak muda itu bernama Wawan Agus, sering dipanggil Wawan. Dia bergaya bak anggota polisi atau TNI, padahal Wayan hanya seorang guru SD mata pelajaran olahraga. Statusnya masih guru kontrak pula. Namun, Koplak mengakui, bentuk tubuh Wayan memang betul-betul memikat." (Rusmini, 2019:8).

Data di atas menjelaskan kekuasan yang dimiliki Wawan dan kelebihan fisik Wawan yang rupawan menjadi salah satu alasan dan ancaman bagi Koplak dalam persaingan merebut jabatan sebagai kepala desa. Konflik politik dijelaskan melalui jabatan Wawan sebagai guru SD dan kelebihan yang dimiliki Wawan dalam bentuk fisiknya yang seperti polisi dan TNI supaya dapat menjadikan kelebihan Wawan menjadi kepala desa dan dapat bersaing dengan Koplak. Selain itu, ditunjukan dengan calon kepala desa yang lain dengan data sebagai berikut.

"Apalagi calon ketiga. Lelaki satu ini terlihat gagah. Konon, dia pernah menjadi kepala sekolah di kota. Idenya banyak. Setiap berpidato di balai banjar, orang-orang desa bengong dan linglung. Bahasanya tertata manis. Kelihatan sekali sewaktu sekolah dulu I Putu Anas 

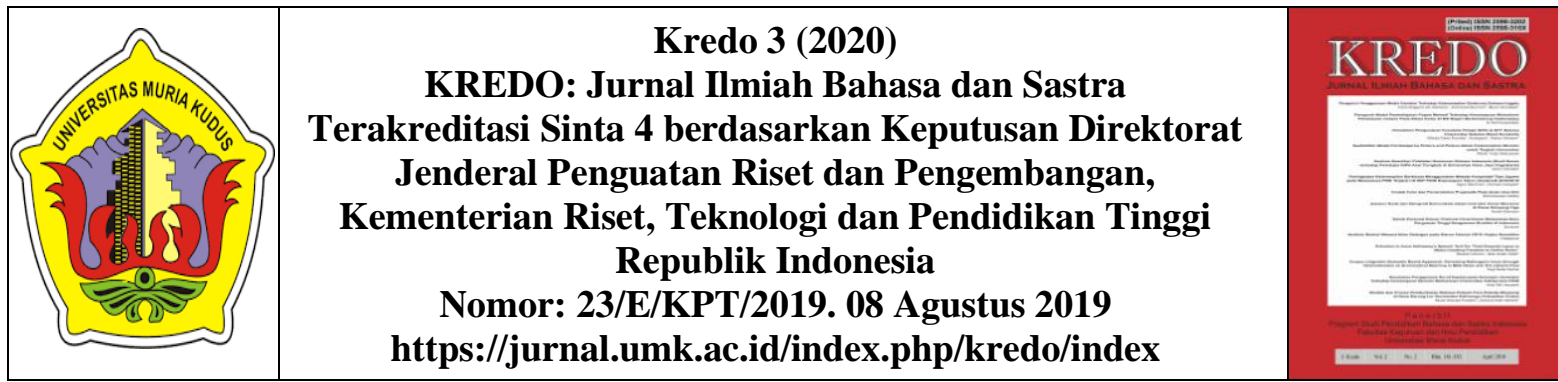

Grabag pasti selalu jadi juara." (Rusmini, 2019: 11).

Kekuasaan yang dimiliki I Putu Anas Grabag adalah kekuasaan sebagai rekam jejaknya yang dapat menjadikannya meraih kekuasaan sebagai kepala desa. Dengan latar belakang pernah menjadi kepala sekolah di kota, akan menjadikan pandangan masyarakat terhadapnya menjadi baik. Di samping sepak terjangnya yang pernah menjadi kepala sekolah, I Putu Anas Grabag juga merupakan orang yang kaya raya.

"Dia lelaki cerdas. Mantan kepala sekolah sebuah SD terpandang di kota, bisik si pendukung Putu Anas, bangga. Duitnya banyak. Jangankan jembatan bambu, jembatan beton pun akan dibangun di desa ini, kata pendukung Putu Anas lebih serius dan berapi-api." (Rusmini, 2019: 11).

Dijelaskan melalui percakapan pendukung Putu Anas, bahwa Putu Anas adalah seorang yang kaya raya. Ia mampu membuat desa dengan membangunkan jembatan beton, dan bukan jembatan bambu lagi. Selain itu, Putu Anas adalah lelaki yang cerdas, dirinya mampu menjadi kepala sekolah di sebuah Sekolah Dasar yang terpandang di kota. Hal ini membuktikan bahwa Putu Anas memiliki sepak terjang yang jauh dari kandidat calon kepala desa sebelumnya. Kekuasan yang berupa jabatan sebagai kepala sekolah di SD ternama, menjadikan ia memiliki pandangan tersendiri di mata masyarakat.

"Bape, jangan mau enak sendiri. Bape tahu, tidak? Mempekerjakan anak-anak dilarang oleh negara. Suara Kemitir terdengar keras dan penuh ancaman di telepon. Koplak pun membelah diri. Bape tidak mempekerjakan anak-anak! Itu Lindung! jawab Kemitir, setengah berteriak. Bape menolong dia. Bape.... Bape. Bape suruh ini-itu, lalu Bape bayar. Hati-hati nanti kena UU Perlindungan Anak! Hukumannya tidak main-main, Bape..... Suara Kemitir dari seberang terdengar hati-hati. Dan, Kemitir pun menjelaskan pelan-pelan kepada ayahnya tentang Undang-Undang itu." (Rusmini, 2019: 126).

Konflik politik yang terjadi pada data di atas menjelaskan jika Perlindungan Anak yang melakukan suatu pekerjaan. Hal ini dijelaskan oleh putri dari Koplak yang menjelaskan bagaimana bahaya dari Undang-Undang Perlindungan Anak tersebut. Ini dilakukannya karena koplak mempekerjakan anak bernama Lindung untuk menjadi pelayannya dan dibayar oleh Koplak. Tepisan koplak akan hal ini menyatakan bahwa ia tidak mempekerjakan. Koplak dengan segala keputusanya kepada Lindung adalah semata-mata untuk membantunya, agar dia mendapatkan pekerjaan. Melihat latar belakang Lindung yang berasal dari keluarga yang tidak jelas orang tuanya. Bahkan dia bingung dalam keseharian dalam hidupnya.

"Kamu merasa tulus memberi cinta untuk anak perempuanmu? tanya Pan Balung pada suatu senja. Cintaku pada anak perempuanku tidak tergantikan. Tetapi kamu pamrih. Persis seperti orang-orang politik itu, kerjanya menebar janji. Mereka juga selalu membawa 


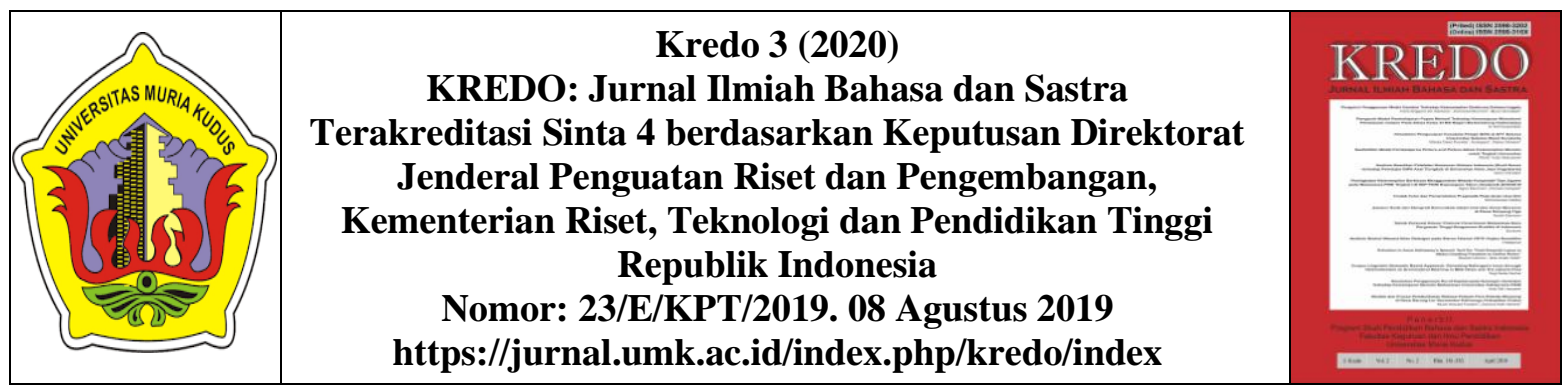

ketulusan, kedamaian, cinta dan kasih yang mereka tebarkan bak seorang dewa yang benar-benar sempurna. Turun ke pasar becek. Makan di warung kaki lima yang biasanya diperuntukkan untuk rakyat. Tetapi, pulang dari warung dan makan di kaki lima yang hiruk-pikuk di pasar dijamin mereka pasti minum obat mencret. Pan Pan Balung terbahakbahak." (Rusmini, 2019:92)

Data di atas menunjukkan adanya kritik terhadap politik yang sedang terjadi. Hal ini dilakukan oleh Pan Balung terhadap Koplak Pan Balung meceritakan bahwa, pejabat yang sekarang ini melakukan tindakan untuk makan di kaki lima dan turun ke pasar yang becek adalah semata-mata mencari sebuah nama di muka umum. Lantas dari apa yang yang dilakukan itu nantinya seorang pemimpin akan meminum obat mencrek. pandangan Pan Balung beranggapan jika pemimpin saat ini tidak benar-benar tulus, melainkan hal seperti itu dilaukan agar dia mendapatkan citra baik di depan umum.

"Demokrasi yang sehat Itu membutuhkan kritik dan aspirasi masyarakat untuk mengontrol kekuasaan. Kalau penyelenggara negara tidak mau dikritik, siapa yang akan mengingatkan mereka? Siapa yang akan mencaci kerja dan kekuasaan mereka? Karena kekuasaan cenderung membuat seseorang berperilaku korup. Kau bisa hitung, berapa ratus penyelenggara negara yang ditangkap KPK? Banyak OTT, operasi tangkap tangan. Memalukan! Apa jadinya negara ini kalau orangorang seperti itu tidak boleh bersuara? Sadar nggak sih mereka, sesungguhnya mereka ada karena

216 | Jurnal Kredo Vol. 3 No. 2 April 2020 kita, rakyat! Mereka bisa dapat fasilitas karena uang dari kita, rakyat! Pan Balung menggelenggelengkan kepalanya." (Rusmini, 2019:95).

Keadaan politik yang diceritakan oleh Pan Balung memiliki representasi terhadap keadaan politik saat ini. Banyaknya kasus korupsi yang terungkap oleh KPK dan banyaknya OTT yang ditemukan KPK menjadikan kritik serius dari masyarakat yang diwakilkan oleh Balung. Dalam hal ini Pan Baung mewakili suara rakyat yang disampaikan kepada Koplak terkait keluh kesah terhadap situasi dan kondisi yang saat ini terjadi. Koplak menanggapinya dengan serius dan mengerti keadaannya. Sebagai pemimpin ia harus mendengar suara rakyatnya. tidak terkecuali Pan Balung ketika berbicara dengan Koplak.

"Indonesia ini makin hari makin aneh, Bape. Orang bisa menjual agama dan Tuhan untuk tujuan mereka sendiri. Dilarang beginibegitu. Aturannya makin rumit. Masa menghadap Tuhan saja harus repot? Ada aturan mainnya. Ada pakemnya. Wah, kalau begitu lama-lama menghadap Tuhan itu perlu kursus? Atau, perlu latihan sehingga berdoa pun ada tips-tipsnya. Gila juga. Suatu hari kemitir menggerutu." (Rusmini, 2019:138-139).

Data di atas menunjukkan bahwa terjadinya politik yang saat ini terjadi. Hal itu dijelaskan melalui tokoh Kemitir kepada Koplak ayahnya. Ia merasa Indonesia semakin lama semakin menggila. Agama dan Tuhan ikut 


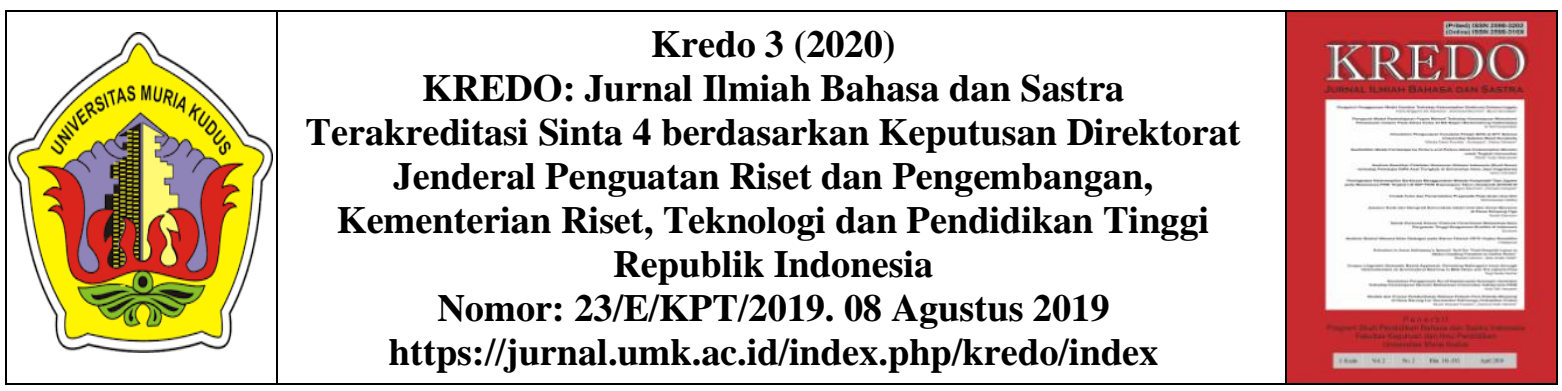

disangkut pautkan dengan politik. Ketika menghadap Tuhan pun, terlalu banyak aturan. Oleh karena itu, pernyataan Kemitir berasumsi akan adanya kursus tentang menghadap Tuhan dan dalam kegaiatan berdoapun akan ada tipstipsnya. Orang bisa menjual agama dan Tuhannya melalui politik. Hal ini merupakan salah satu tujuan dari beberapa golongan yang terdapat di dalam dunia politik. Tujuan tersebut semata-mata untuk mendapatkan kursi kekuasaan. Dengan latar belakang agama, yang akan menjadi bekal bagi kelompok politik dalam merebutkan kekuasanya.

"Dunia ini makin hari makin aneh bagi Koplak. Sejak kapan orangorang begitu hiruk-pikuk mengatur cara "bertamu" ke rumah Tuhan? Bahkan, cara orang "bertamu" juga seolah menunjukkan kualitas dan kedalaman Iman, bahwa kebenaran itu hanya milik mereka. Kenapa belakang ini orang-orang sering sekali mengurusi hal-hal yang tidak penting? Hal-hal yang harusnya tidak jadi prioritas. Semua diurusi, terasa getas. Sejak kecil Koplak telah diajari cara mengenal-Nya dengan caracara sederhana." (Rusmini, 2019:139).

Data di atas menunjukkan adanya permasalahan politik yang disangkut pautkan dengan agama. Peraturan baru dibuat untuk umat beragama dalam melakukan ibadah kepada Tuhan. Kualitas dan keadaan Iman seseorangpun dipandang melalui cara mereka bertamu kepada Tuhan. Cara bertamu kepada Tuhan menunjukan bahwa kedalaman dan kualitas iman seseorang itu baik, begitu pula dengan sebaliknya. Hal yang tidak perlu diutamakan, dalam permasalahan ini menjadi utama. Sehingga hal yang paling pentingpun malah dilupakan. Oleh karena itu, Koplak merasakan perbedaan dengan apa yang ia dapatkan semasa kecil. Beribada dengan tujuan mendekatkan dirinya kepada pencipta melalui cara-cara yang sederhana. Hal itu berbeda dengan apa yang dirasa Koplak sekarang.

"Koplak menarik napas panjang sambil melepas sarung dan membiarkan ketukan pintu di depan rumah. Siapa, sih, yang bertemu pada hari Minggu? gumamnya, sedikit menggerutu. Kamu itu, kan pejabat. Jangan sok angkuh dan sok bangsawanlah. Masa orang bertamu pada hari Minggu tidak boleh? Jadi orang nomor satu di desa, kau harus siap menjadi pelayan! Pelayan! Bukan bangsawan! Kau menjadi pejabat untuk melayani! Bukan dilayani? Mengerti?! Suara hatinya tiba-tiba membuat koplak kehilangan selera menghisap rokok lintingan sisa kemarin sore." (Rusmini, 2019: 152).

Suara Hati koplak mewakili tentang kondisi seorang pemimpin saat ini. Dimana pemimpin saat ini Ketika hari libur tidak akan melayani masyarakatnya karena buka jam berkeja baginya. Hal ini berbeda dengan Koplak berpikir bahwa yang harus dilayani adalah rakyat dan bukan dirinya. Dia adalah pelayan rakyat yang sewaktu-waktu selalu ada untuk rakyat dalam situasi rakyat membutuhkan dirinya. Sehingga dia tidak perlu berperilaku seperti bangsawan, yang harus dilayani oleh masyarakat, tetapi sebaliknya. Hadirnya ketukan pintu tersebut menjadikan 


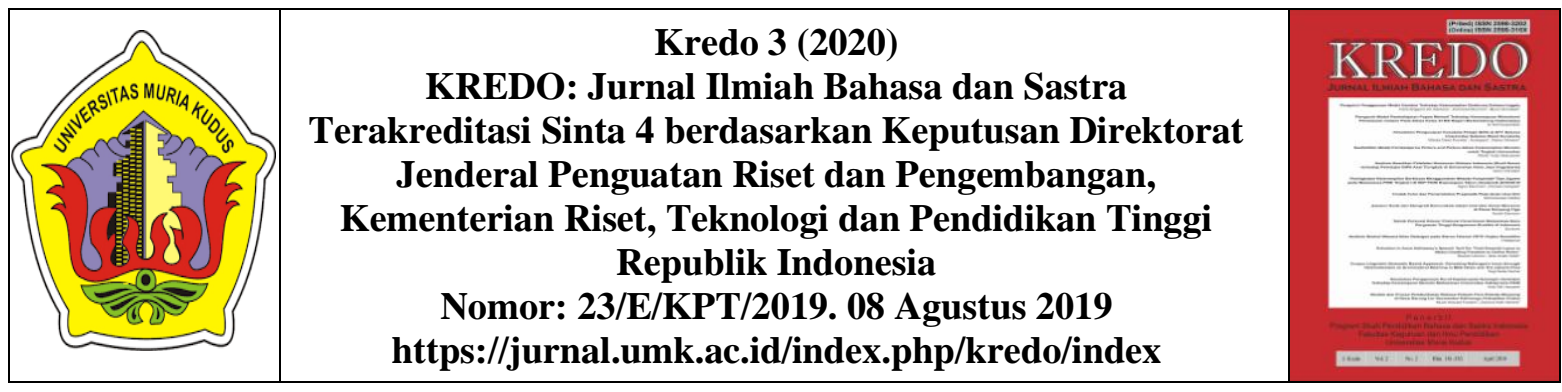

Koplak mementingkan kepentingan orang lain dari pada kepentinganya untuk bersantai.

"Harum kopi membasuh Koplak, semoga pada bulan Juni, Indonesia mampu menata hidupnya lebih baik. Tapi, itu kan tahun pilkada, Pak Kades. Makin banyak orang mabuk. Banyak orang terserang penyakit kekuasaan dan menghalalkan apa saja untuk meraih kekuasaan. Sahut sebuah suara yang dikenal Koplak." (Rusmini, 2019: 176).

Data di atas menunjukkan keadaan politik yang sedang terjadi. Pada bulan Juni Indonesia mampu menata hidupnya dengan pemilihan kepala pemerintahan yang baru. Di dalam pemilihan kepala pemerintahan yang baru ini akan menimbulkan banyak sekali permasalahan mulai dari penyakit kekuasaan yang akan dilakukan oleh kandidat atau calon kepala pemerintahan untuk melakukan segala cara. Hal ini dengan tujuan mendapatkan kursi jabatan. Perkataan itu seketika terdengar di telinga Koplak.

\section{SIMPULAN}

Kesimpulan dari adanya penelitian ini mengungkapkan hegemoni kekuasaan melalui kelompok sosial (mendominasi dan didominasi), supremasi kekuasaan intelektual dan moral melalui pendidikan dan agama, dan konflik politik. Hegemoni kekuasaan melalui kelompok yang mendominasi dan didominasi. Kelompok yang mendominasi melalui jabatan di pemerintahan, tidak selamanya mendominasi lingkungan sekitarnya. Melainkan di dalam penelitian ini sebaliknya, yaitu pemndominasi menjadi yang didominasi. Supremasi kepemimpinan intelektual dan moral ditunjukan oleh kaum yang sebagai didominasi, tetapi dapat mendominasi. Anak Koplak mendominasi Koplak yang semestinya Koplak yang melakukan dominasi, melalui pendidikannya. Selain itu, sahabat Koplak, mendominasi Koplak melalui agama yang mengacu kepada konteks politik yang tidak sehat, akan berakibat kepada hukum yang ditunjukan melalui agama. Hal ini sebagai bentuk konsekuensi dari suatu perbuatan yang dilakukan. Konflik politik ditunjukan melalui upaya dalam merebutkan kursi kekuasaan, yaitu sebagai Kepala Desa. Konflik dari itu, ditunjukan melalui tingkah laku kandidat calon Kepala Desa.

\section{DAFTAR PUSTAKA}

Akbar, S. 2012. Kajian Sosiologi Sastra dan Nilai Pendidikan dalam Novel Tuan Guru Karya Salman Faris. Universitas Sebelas Maret Surakarta.

Damono, S. D. 1979. Sosiologi sastra: Sebuah Pengantar Ringkas. Jakarta: Pusat Pembinaan dan Pengembangan Bahasa.

Falah, F. 2018. Hegemoni Ideologi dalam Novel Ketika Cinta Bertasbih Karya Habiburrahman el Shirazy (Kajian Hegemoni Gramsci). NUSA, 13(4), 533-542.

Gramsci, A. 1971. Selections from Prison Notebook, edited and translated by Quentin Hoare and Geoffray $N$ Smith. London: Lawrenceadn Wishart. 


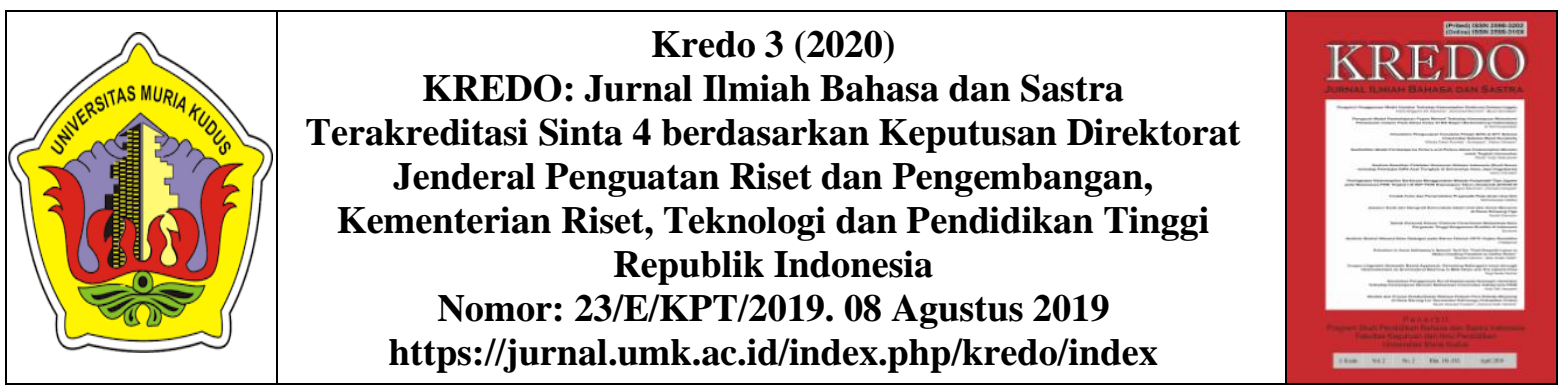

Hutagalung, D. 2004. Hegemoni, Kekuasaan, dan Ideologi. In Jurnal Pemikiran Sosial, Politik, dan Hak Asasi Manusia (Vol. 74, pp. 1-17).

Idayatiningsih, R. 2017. Perlawanan terhadap Dominasi Kekuasaan dalam Novel Pasung Jiwa Karya Okky Madasari (Analisis Wacana Kritis). Lingua Franca: Jurnal Bahasa, Sastra, Dan Pembelajarannya, 5(2), 42-62.

Miles \& Huberman. 2009. Analisis Data Kualitatif. Jakarta: Universitas Indonesia Press.

Nakrowi, Z. S. dan A. P. 2019. Strategi Kesatuan Berbahasa Suku Jawa dalam Interaksi Antarsuku di Halmahera Utara. RETORIKA: Jurnal Bahasa, Sastra Dan Pengajarannya, 12(1), 105-116. https://doi.org/10.26858/retorika.v1 2i1.6909

Putra, C. R. W. 2018. Cerminan Zaman dalam Puisi (Tanpa Judul) Karya Wiji Thukul: Kajian Sosiologi Sastra. Kembara: Jurnal Keilmuan Bahasa, Sastra, Dan Pengajaranya, 4(1), 12-20.
Rahmat, L. I. 2019. Kajian Antropologi Sastra dalam Cerita Rakyat Kabupaten Banyuwangi pada Masyarakat Using. Jurnal Kredo, 3(1), 83-93.

Rusmini, O. 2019. Koplak. Jakarta: Penerbit Grasindo, Anggota IKAPI.

Semi, A. 1993. Metode Penelitian Sastra. Bandung: Angkasa.

Setiawan, A. 2018. Pandangan Hidup Wanita Jawa dalam Novel Bekisar Merah Karya Ahmad Tohari. Jurnal Kredo, 1(2).

Swingewood, A. 1992. A Short History of Sociological Thought. London: Macmillan Press.

Wahyudi, T. 2013. Sosiologi Sastra Alan Swingewood Sebuah Teori. Jurnal Poetika, 1(1), 55-61.

Widada, R. 2009. Sausur untuk Sastra Sebuah Metode Kritik Sastra Struktural. Yogyakarta: Jalasutra.

Wijakangka, A. R. 2008. Analisis Hegemoni Kekuasaan dalam Novel Pabrik Karya Putu Wijaya. Jurnal Artikulasi, 5(1), 187-213. 